Revue belge de géographie

\title{
Immigrants from Balkan countries in Greece: local and transnational processes of incorporation in Thessaloniki
}

Les immigrants des pays balkaniques en Grèce: processus locaux et

transnationaux d'intégration à Thessalonique

\section{Panos Hatziprokopiou}

\section{CpenEdition}

\section{Journals}

\section{Electronic version}

URL: http://journals.openedition.org/belgeo/12474

DOI: $10.4000 /$ belgeo.12474

ISSN: 2294-9135

\section{Publisher:}

National Committee of Geography of Belgium, Société Royale Belge de Géographie

\section{Printed version}

Date of publication: 30 June 2005

Number of pages: 163-174

ISSN: 1377-2368

Electronic reference

Panos Hatziprokopiou, "Immigrants from Balkan countries in Greece: local and transnational processes of incorporation in Thessaloniki", Belgeo [Online], 1-2 | 2005, Online since 27 October 2013, connection on 05 February 2021. URL: http://journals.openedition.org/belgeo/12474 ; DOI: https:// doi.org/10.4000/belgeo.12474

This text was automatically generated on 5 February 2021.

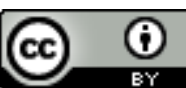

Belgeo est mis à disposition selon les termes de la licence Creative Commons Attribution 4.0 International. 


\title{
Immigrants from Balkan countries in Greece: local and transnational processes of incorporation in Thessaloniki
}

\author{
Les immigrants des pays balkaniques en Grèce: processus locaux et \\ transnationaux d'intégration à Thessalonique
}

Panos Hatziprokopiou

\section{AUTHOR'S NOTE}

This paper was presented at the International Conference on Human Mobility in a Globalising World, organised by the International Geographical Union Commission "Global Change and Human Mobility" together with the University of Balearic Islands, and held at Palma de Mallorca during 3-5 April 2003.

\section{Introduction}

1 Contemporary international migration is seen as an increasingly globalised phenomenon with qualitatively new characteristics (Castles and Miller, 2003). Some of the current migration trends are clearly manifested in the experience of Greece as a migrant receiving country. Its position at the south-eastern corner of the European Union (EU) makes migration to Greece of particular interest for Europe as a whole. Immigrants come from a large number of countries and through a variety of channels and routes; there can be observed several forms of migration and various categories of migrants. Generally, the Greek experience of immigration is understood within the wider context of the transformation of Southern Europe into a new destination region for migrants from Eastern Europe and the less developed world. Both international and 
domestic factors, related to economic and political change, demography, history and culture, have contributed to this transition so that we can speak of a distinct Southern European model of migration (King, 2000). However, the Greek case is unique in respect to the regional dimension of the vast majority of migratory flows and the sudden and unexpected immigration "boom" in the early 1990s.

2 The 2001 Census counted 797,091 "aliens" living in the country, a figure which, whatever the possible biases, suggests a high share of foreign nationals in a total population of 10,964,020. Among the 371,641 immigrants who applied for regularisation in 1998, 77.1 per cent came from the neighbouring Balkan countries: 65 per cent from Albania, 6.7 from Bulgaria and 4.5 from Romania (Cavounidis and Hatzaki, 1999). The factor of proximity clearly conditions population movements between Greece and the Balkans, highlighting thus the importance of geography in shaping migratory patterns. Proximity, though, is important not only in respect to labour flows: the migration phenomenon in Greece seems to be part of a wider context of mobility that can be observed in the post-1989 Balkan space. The opening of the Balkan markets has contributed not only to a rise in intra-Balkan commercial activity, but also to the penetration of Greek capital into Balkan economies in the form of foreign direct investment (FDI): alongside its transformation into a migrant receiving country, Greece has also shifted from being a net importer to an exporter of capital (Labrianidis et al., 2004). In 1998, about 82 per cent of an estimated total of 1270 Greek investment projects in Eastern Europe was concentrated in the three Balkan countries from where the majority of migrants come: 41.1 per cent in Bulgaria, 20.3 in Albania and another 20.3 in Romania. Consequently, apart from labour flows from Balkan countries to Greece, there have also appeared population movements from Greece to the Balkans, naturally accompanying trade and capital flows (merchants, distributors, business executives, investors, etc.), so that it has been suggested that a Greek "diasporic" network is emerging in the region (Kamaras, 2001).

The city of Thessaloniki is the second largest urban concentration in Greece; its location is of particular geo-economic significance for the country and for the wider Balkan area. It has historically been an important commercial centre during the Roman, Byzantine and Ottoman periods and it hosted for centuries populations from all over the region as well as a large community of Sephardic Jews. The new Balkan geography offers Thessaloniki the opportunity to become a regional metropolitan centre in South-East Europe (Giannakou and Kafkalas, 1999). Regarding immigration, 26,431 of the immigrants registered in 1998 in Greece (7.1 per cent of the total) were living in the prefecture of Thessaloniki, more than 80 per cent of whom were from Balkan countries: Albanians in the great majority ( 75 per cent), followed by Georgians and Bulgarians (Cavounidis and Hatzaki, 1999) ${ }^{1}$.

4 The aims of this paper are to identify and describe the processes and patterns of the incorporation of immigrants from Balkan countries in the city, and to explore the links between what is taking place in Thessaloniki and broader developments and trends at the international level. Empirical material has been collected between September 2001 and February 2003 through questionnaires and interviews with 138 Albanian and 70 Bulgarian immigrants living and working in the city ${ }^{2}$. Among the Albanians, 34 per cent are of ethnic Greek origin; in the case of Bulgarians, the share of ethnic Greeks was lower, at 29 per cent $^{3}$. With respect to age, the two migrant groups are rather similar, since the majority (about 60 per cent for both nationalities) is between 20 and 39 years 
old. Regarding gender, the two migrant groups exhibit an important difference, as Albanian women form only one third of the Albanian sample, while half of the Bulgarian migrants are female. Regarding family status, 62 per cent of the Albanians and half of the Bulgarians are married, while more than half of both groups have children ${ }^{4}$.

5 The paper develops a transnational perspective in order to understand incorporation processes by looking at different overlapping "layers": a global, a regional, a national and a local one. The analytical framework is based on the theoretical insights for the study of the modes of "incorporation" or "integration", as proposed by Portes (1995, pp. 24-25) and Musterd et al. (2000), respectively. Alejandro Portes calls "modes of incorporation" the interaction of governmental policy, civil society/public opinion and ethnic community/social networks as structural and relational forms of embeddedness which determine "the process of insertion of immigrants" in the host society. On the other hand, Musterd and his colleagues refer to market exchange/economic restructuring, redistribution/welfare and reciprocity/social networks, as the contexts shaping immigrants' integration in the destination place, together with the sociospatial dimension. Although following different explanatory patterns, the above ideas are critically combined in order to organise the analytical narrative around different but interconnected "levels" of immigrants' incorporation:

- a socio-political level, focusing on the polity's and civil-society's "responses" to immigration;

- a socio-economic level, concerning the labour market integration of immigrants in Thessaloniki;

- a socio-spatial level, regarding the relation between immigration and urban geography.

\section{Social and political responses to immigration}

The political context in the host country is certainly the most influential factor regarding the social incorporation of immigrants. Immigration policy determines the legal framework regarding entry, residence and work, while welfare provisions condition largely the extent to which migrants can build a decent life at the host country, whether temporarily or permanently. Having to deal with increasing migratory pressures on the one hand, and confronted with a sharpening crisis of the welfare state on the other, European governments are faced both with an already present migrant population living in a socially dangerous position and with multiplying xenophobic reactions. Furthermore, the action of Non-Governmental Organisations (NGOs), political groups and other institutions has been crucial for bringing immigrants' problems to the forefront, for providing material support and for diffusing values of solidarity and mutual understanding. As generally in Southern Europe, the Greek social state has been developed at a late stage, and it is also characterised by certain weaknesses, malfunctions and bureaucracy, with the family still playing a crucial role in compensating for some of the inadequacies of the welfare system; it has not escaped, though, the pressures evident in Northern European welfare regimes (Symeonidou, 1996).

7 It seems that the socio-political context of immigrants' incorporation in Greece reflects to an extent the contemporary crisis in the functions and role of the nation state and in the collective national imaginary. To begin with, the phenomenon of irregular 
movements is produced by the contradiction between closed borders and growing migration, and by definition violates the territory of the nation state. Greece was the last Southern European country to undertake measures for the regularisation of undocumented foreigners, keeping the vast majority of immigrants under clandestine status until 1998. Among the respondents in my survey, 41 per cent of the Albanians and 17 per cent of the Bulgarians came by illegally crossing the border, while another 57 per cent and 42 per cent of them respectively used tourist visas to enter and then extended their stay illegally.

Furthermore, the erstwhile autonomy of national governments in decision-making processes is undermined by growing international interdependence and by integration into supranational political units. In the case of Greece, immigration policy is influenced by obligations arising from membership in the EU and from international agreements like Schengen, while at the same time it involves foreign policy and diplomatic relations with neighbouring countries. According to Baldwin-Edwards and Fakiolas (1998), Greek policy through the 1990s has been shaped by three basic factors: an institutional-bureaucratic one, characterised by traditional structures and xenophobic attitudes; a modernising-technocratic one, which sees immigration as a reality and rethinks Greek citizenship; and the factor of external relations with Balkan countries and the EU. Greece had to cope with the obligations arising from membership in the EU, perhaps more urgent in its case due to its geographic location. The repressive logic of the initial legal framework is partly attributed to the need of the country to be in-line with the European guidelines (Karydis, 1996). Furthermore, Greece's diplomatic interests in the Balkans, especially regarding the ethnic Greek minorities in Albania and Bulgaria, conditioned in a broad way its policy towards immigrants from these countries. Inspired by outdated notions of national belonging and of selective definitions of "Greekness" the state treated in a very differential way such immigrant groups (Triandafyllidou and Veikou, 2002). While the majority of immigrants are entitled to residence/working permits, ethnic Greek Albanians get a special identity card, which is neither a stay permit nor gives them full citizenship rights; on the other hand Bulgarian Sarakatsans get a special visa, which they have to renew every year.

Furthermore, both immigration policy and the public discourse on immigration reflect the exclusionary construction of the Greek national identity, which defines the concept of "Greekness" mostly on the basis of religious, linguistic and genealogical criteria, rather than civic ones (Triandafyllidou and Veikou, 2001). The initial, and to a certain degree expected, xenophobic reactions gave way to open racist feelings towards migrants. Especially Albanians, given that they represent by far the largest immigrant group, have been the victims of a widely spread "Albanophobia", which in some cases was manifested in extreme ways (violent attacks, massive deportations). Problems such as the increasing unemployment and the rise in criminality during the 1990s have been the main arguments used in racist discourse, connected directly to the arrival of migrants. The experiences of Albanian and Bulgarian immigrants in Thessaloniki clearly confirm this situation. About half of the Albanians consider police and the media to be "hostile" towards them, although far fewer Bulgarians report such problems. The detailed interviews uncover experiences of discrimination and/or offensive treatment of both nationalities, far more evident in the case of the Albanians. 
10 Partly at least, the police-logic of governmental policy stigmatised immigrants through the criminalisation of their illegal status, building thus the stereotype "illegal immigrant = Albanian criminal" (Karydis, 1996). Racism has been cultivated to a great extent through reactionary media discourse, but it found a basis on historically-built attributes of the Greek national myth ${ }^{5}$. However, as we are going to see in the next section, there is also a socio-economic aspect of discriminatory practices: most immigrants do dirty, badly paid jobs that Greeks are rejecting, and in that sense they form a class of "servants"; this suggests that, alongside with widespread prejudices, towards Albanians mostly, the routes of racism lie within class relations as well. In general, it is national identity that is being transformed, as it gets exposed in an increasingly global environment where old certainties are being eclipsed, while at the same time it is confronted directly with the "Other" who is now here and among "Us", and thus expresses itself in reactionary and exclusionary ways.

\section{Labour market integration}

11 The employment of immigrants obviously depends on the characteristics of the labour market and more precisely, on the productive and employment structures of the specific localities in which they live and work. Local labour markets, although historically and geographically shaped, operate within national patterns of regulation of economic activity and, ultimately, are increasingly subject to global forces of economic restructuring. Therefore, the issue of the immigrants' labour market integration has to be understood in relation to the productive and employment structures of Thessaloniki and their dynamics of change. Broadly, we have an urban labour market where traditional, informal, labour-intensive activities coexist with modern, formal and capital-intensive ones (Vaiou and Hadjimichalis, 1997, p.131, table 4.9). A significant part of industrial activity remains unrecorded and is based on small and medium scale enterprises, often family owned and family-run, using mainly labour-intensive practices (Cronaki et al., 1993). The city has historically been an important commercial centre and its economy has relied significantly on the service sector, while trends of further tertiarisation can be observed (Giannakou and Kafkalas, 1999). The recent changes in consumption attitudes are characterised by two major trends: the persistence of massive demand for "fordist-type" products and services and the shift towards more individualised forms of demand.

In general, immigrants in Greece tend to be occupied informally in low paid, low skilled jobs, in sectors and areas where there are shortages of labour and in posts rejected by the locals. Among male respondents of both nationalities, 26.5 per cent were employed in construction, 22.7 per cent in manufacture, 14.4 per cent as assistant manual workers in small companies and another 11.3 per cent as craftsmen/technicians. Among women, 31.6 per cent were domestic servants or carers, 17.1 per cent were assistants in small retail shops, or in bars, cafes, restaurants and hotels and 13.1 per cent were working as manufacturing workers. It is clear that domestic and care work for women is as important as construction is for men, keeping in mind that construction jobs also involve employment directly by individuals and/or households for repair works, tiling, painting, etc. Employment in industry comes second for both sexes and it is concentrated mostly in small clothing manufactures for women and in industries and workshops in the sectors of metal, oil and chemicals, furniture, clothing 
and shoe-making for men. In general, there is no evidence of significant differences between the two immigrant groups: the only notable one is a slight higher "specialisation" of Bulgarian women in care work as live-in maids, as well as in employment in bars, cafes, restaurants and hotels, while there are more Albanian men employed as craftsmen in workshops and assistant workers in small companies. So, despite the overall weight of the Albanian element, specific "ethnic" employment clusters are not apparent, at least as a general feature of immigrant labour in Thessaloniki. Regarding remuneration, the sample is characterised by a high degree of heterogeneity, depending on the type of occupation and the position held, but also on the period a person works for the same employer. For instance, the daily wage for a manual worker in small industrial workshops and in construction sites varies from 23 to 32 Euros, while a domestic servant/cleaner gets between 10-30 Euros per day, depending on the hours of work. The share of those having registered employment is rather low (about half), even lower in the case of women (about 30 per cent), although a greater percentage of Bulgarian workers actually have social security. These differences have to be understood on the basis of the interaction between the immigrants' clandestine status (previously a rule for the majority), the role of informal social networks in job-finding strategies, and the structure of the labour market itself. of particular interest are two specific characteristics of immigrant employment in urban labour markets:

Firstly, the companies where immigrants work, whether in construction, manufacture or services, are in most cases small and medium sized enterprises (SMEs), representing a common general feature of employment and productive structures in Greece and Thessaloniki (see Fakiolas, 2000).

Secondly, the weight of services, especially personal ones directed towards households or individuals, constitutes an important qualitative difference from post-war labour migration in Europe and elsewhere (Pugliese, 1993).

Both features reflect the segmentation of the labour market in Thessaloniki, which is related equally to the persistence of traditional productive structures and to the generation of new trends as a result of increasing exposure to the international forces of economic restructuring (Vaiou and Hadjimichalis, 1997, pp. 52-53). After all, informal economic arrangements are a general feature of Southern European economies, and have functioned to an extent as a "pull-factor" for immigration (King, 2000). In addition, processes of further tertiarisation of production and employment seem to deepen the polarisation between skilled and unskilled labour and to lead the latter towards the informal sector, as has been observed in contemporary urban labour markets of highly developed countries (Sassen, 1996). Finally, we can identify a tendency of a section of immigrant labour to be employed in personal services, to a large extent related to reproductive activities such as care, domestic or house-repair works that previously would be done by members of the household (see also Psimmenos and Kassimati, 2002).

Informal practices are common among SMEs in Greece, which show an increased demand for cheap and flexible labour. Such companies are threatened by a sharpening crisis stimulated by international competition and since many are unable to modernise, they tend to apply labour-intensive practices and seek to reduce their production costs through tax evasion, low wages and the employment of unregistered labour. Mobility is a key to the solution of their competitive problems, not only in the form of labour flows 
in Greece, which they can employ cheaply and flexibly at home, but also because many companies move to the neighbouring Balkan countries, where they can exploit at even more profitable conditions the local labour force. As mentioned in the introductory section, this is the dominant type of entrepreneurial behaviour among Greek companies investing in Balkan countries (Labrianidis et al., 2004). In that sense, the Balkans constitute a "pool" of cheap labour force which can satisfy the demands of a section of Greek small capital either domestically (immigration), or abroad (FDI). For instance, the early 1990s crisis in the clothing manufacture of Thessaloniki has been, to an extent, overcome through the informal employment of immigrant women (Chronaki et al., 1993), although ultimately there is a trend of many companies in the sector to move their activities abroad.

On the other hand, the expansion of the middle classes and the high incomes earned by businessmen and highly skilled personnel, generate a demand for hotel, catering, entertainment, domestic and other services (Fakiolas, 2000, p. 60). Psimmenos (1998) underlined the increasing importance of private/personal services for the employment of Albanians in Athens: growing personal consumption generates a demand for immigrant workers to be employed as domestic cleaners/servants, manual workers performing house repairing tasks, general store assistants, etc. Additional factors such as the increasing participation of women in the labour force, the continuous enlargement of the housing space, the ongoing ageing of the population and the inadequate number of state kindergartens and care-institutions for the elderly, together with the still low participation of men in housework have contributed to rises in the demand for reproductive activities (Fakiolas, 2000). To an extent, in all Southern European countries the exodus of women to the labour market has been further facilitated through the employment of female immigrants in the household (King and Zontini, 2000). For several reasons, reproductive activities have become an important sector of immigrant employment across the EU (Anderson, 2001).

In general, migrants from Balkan countries suddenly found themselves in a situation of market competition, and they have been exposed to new consumption values and "Western" life prospects. In order to overcome financial problems, immigrants seem to throw away, at least for a certain period, what can be characterised as accepted standards of dignified employment and perform any job in order to survive or to support their families back home. Many sacrifice their present for gaining a future life in dignity. Work seems to have become an important value for them, strong enough to make them accept the "servile" jobs they are offered in Greece, especially construction, domestic or care workers (see Psimmenos and Kassimati, 2002). In that sense, a new social group has been formed, a "servant" working class, which offers informal, flexible and low-paid labour and performs difficult manual tasks, which the indigenous population is more and more unwilling to undertake.

\section{Immigration and urban social space}

Urban change is increasingly subject to wide processes of internationalisation. In Thessaloniki we can observe trends of spatial relocation of various activities (production, consumption, residence, leisure), ultimately often accompanied by policies for regeneration and gentrification. Consequently, people's perceptions regarding the use of urban social space change as well. At the same time, the presence of immigrants 
reshapes the face of the city. Certain areas of Thessaloniki, parks and squares, have become places where immigrants gather in order to meet each other or to look for work. Immigrants develop new social uses of the urban space, which acquires a particular meaning for them and becomes their "place". In his study of Albanians in Athens, Psimmenos (1998) has argued that "in socially "dead" places, immigrants organise space" in a completely different way than the indigenous population. To an extent, similar trends can be observed in Thessaloniki.

Regarding housing of the respondents in my survey and their spatial distribution within Greater Thessaloniki, 30.4 per cent of the Albanians were living in the western part of the city, another 63.3 per cent in central Thessaloniki and 7.25 per cent in the eastern part. The equivalent figures for the Bulgarians are 31.4, 45.7 and 22.8 per cent respectively. Most of those living in the central part are concentrated in the areas surrounding the inner city, while the majority occupies rented flats, usually on the ground and first floors. One of the most important features of immigrants' housing experiences in Thessaloniki is the discrimination they face in the housing market. Some landlords are not willing to rent their property to a foreigner, especially to an Albanian: 44.2 per cent of the Albanians and 31.4 per cent of the Bulgarians surveyed reported such discriminatory attitudes of landlords.

To interpret these findings, one should consider the social map of the city, which is seen as divided between the prosperous, more expensive and better-conserved areas of the eastern part and the downgraded, poorer and cheaper areas of the western part, with a socially mixed centre in between. However, social divisions in Thessaloniki are not as sharp as in the Athens conurbation or in other urban areas in Europe, due to the size of the lower middle class cluster of the population, geographically dispersed all over the city. What Leontidou (1997) has observed as a general feature of Southern European cities, that is a relative social mixture of the population in terms of its geographical distribution, applies here to a significant extent, with a traditional trend of the wealthier strata to occupy higher floors and a more recent tendency of some sections to leave the inner city for the (eastern) suburbs. So we find relatively downgraded neighbourhoods within the centre and in eastern Thessaloniki (although by no means they can be characterised as "clusters of poverty") and there are also "nice" areas in the west, while ghetto-like situations have not been observed so far ${ }^{6}$.

The presence of immigrants in wealthy areas should be attributed mainly to employment factors (they live in the districts where there are opportunities for work, or close to their workplace, while a limited amount of men occupy properties provided by their employers and some women work as live-in carers/maids), and to an extent to the functioning of migrants' informal networks (some choose to live to neighbourhoods with a strong presence of compatriots, but while this may be a general feature in the case of Bulgarians, for Albanian migrants it is limited mainly to family ties). A characteristic example is the eastern suburb of Thermi, an erstwhile village which has been recently transformed into a wealthy residential area for mainly upper middle class people who move out of the centre. It is located in the area near the airport, where other activities are also concentrated: places for mass entertainment, large supermarkets, big commercial houses, and small industries. In Thermi, there is a relatively large population of immigrants, mostly from Bulgaria and particularly of ethnic Greek (Sarakatsan) origin. Among the seventeen Sarakatsans in my sample, fifteen were living in Thermi or in surrounding places. Interview analysis uncovered 
network factors that explain this phenomenon: Sarakatsans are characterised as a "closed" cultural group, who tend to socialise mostly with each other, especially the older ones: thus they choose to settle in a district where many compatriots are concentrated, often friends or relatives from home. People who came initially found employment and this attracted others, mostly from the regions of Sliven and Plovdiv? Their housing conditions are quite heterogeneous: men whose families are in Bulgaria tent to occupy bad quality housing, while couples and families tend to live in proper accommodation in flats or houses. Employment is found in the surrounding small industries, workshops and commercial businesses, but mostly in construction activities, repair tasks, gardens and domestic service in the case of women. This is explained on the basis of the particularities of the local socio-economic structures: on the one hand, there are businesses demanding cheap immigrant labour; on the other, there are wealthy residents, who can afford employing a migrant manual worker or a domestic servant to do the housework, to repair the roof, or to look after the garden. The presence of immigrants is visible in the central square of the suburb, where many men gather in the mornings in order to look for work and both men and women spent their afternoons and evenings socialising and chatting. Most of the interviewees talked about good relations with the locals, but they have problems with the police because of the frequent controls: police officers force them to move out of the square in order to "protect" the public image of the centre of Thermi.

Migrants' informal social networks largely condition the location of immigrants, and in some cases they operate as bridges connecting localities in both countries of origin and destination. Such an example can be found in the hidden bonds between Thessaloniki and the Albanian city of Korce. Many Albanians in Thessaloniki come from this particular city: about 30 per cent in my sample, most of whom came directly to Thessaloniki because of the old links between the two cities and of the new connections created by migration. The relationships between Korce and Thessaloniki are rooted back in the 19th century and were shaped by commercial links and by the presence of small Greek and Albanian populations in both cities respectively (although Korce has never been a centre of the ethnic Greek minority in Albania). One of the issues that arose after Korce's autonomy from Ottoman rule (1917) was to become a twin city with Thessaloniki; in 1940 there were at least 350 families of Korceans living in the city ${ }^{8}$. It is true that Thessaloniki used to be the core of commercial activity in the Balkans, not least because the city provided an exodus to the sea. It is believed, though, that special links superseding the economic level existed with a few towns, Korce being one of them. Such bonds are reflected in the personal stories of some of the interviewees, who talk about erstwhile commercial relations, similar traditional architecture and people's movements back and forth before the Second World War. For them, Thessaloniki was the most preferable option regarding settlement in Greece. The existence of a "union of friendship" between the two cities, as part of a wider Association (Epeirotiki Estia), further supports the above observation.

However, nearby a century of nation-building since the integration of Thessaloniki and of the northern part of the country in the modern Greek state has erased these earlier traces from the face and the memories of the city. Old transnational bonds may be crucial for migrants' decision on their place of destination, but they do not seem to make a difference regarding the xenophobic feelings of the locals, who see "foreigners taking over their city". Pavlou (2001, pp. 140-145) analyses local public perceptions of the "proper" use of the urban space, which has to be regenerated and therefore 
"cleaned" of immigrants, whose presence is "annoying" and who "destroy" the public image of specific areas. This kind of exclusionary/discriminatory discourse is supported by existing problems of degradation, misleadingly though linked to the presence of distinct social groups (immigrants, gypsies, beggars, etc.). According to Pavlou, the discourse became more hostile in the year 1997, when Thessaloniki hosted the Cultural Capital of Europe and many areas had undergone through processes of regeneration and of reconstruction of their social use. Regeneration/reconstruction projects, and the increasing use of certain parts of the urban social space for consumption and entertainment, exclude immigrants, among other vulnerable groups, from the use of these particular spaces not only symbolically, but also by their physical removal. However, the settlement of immigrants from Balkan countries in Thessaloniki unavoidably follows a natural path through which they become organic elements of the local society, since they are "here" and here they build their lives.

\section{Conclusion} Albania and Bulgaria in the Greek city of Thessaloniki. These contexts were treated separately for analytical purposes only; in reality, it is their interaction that shapes migrants' lives in the city. Structures, policies and institutions in the host society are the product of historical processes and constitute a single complex that cannot be separated from ideological, cultural and perceptual factors. We have thus seen how immigrants' incorporation is connected to the socio-spatial dynamics of the city and its economic structures, and that these are subject to international forces of restructuring and change.

In the case of Greece in particular, it is essential to understand the dynamic character of the migration phenomenon, the fact that some immigrants "are here to stay", and that their social incorporation is a function of time and place. In addition, the Southern European common immigration patterns prove that the Greek migration experience is subject to wider forces of change. It is important to underline the international dimension of both the migration phenomenon as such, and the process of incorporation of immigrants within the structures and institutions of specific countries and localities. What happens "here", happens in similar ways in other places too. Furthermore, we have to see the Greek experience within its regional dimension. New kinds of flows (migration, trade, capital investment) and new geographies of exchange redefine historical ties, while recently formed social networks are built upon the remnants of an erstwhile cross-border relationship. Communities of origin and destination are connected through the expansion of productive relations beyond national borders and through the operation of social networks of a cross-border character. Such an example of a migration system based on newly formed transnational networks and old patterns of mobility and exchange is represented in the case of Thessaloniki and Korce.

It seems that we are only at the beginning of a new era for the Balkans. The nature of cross border relations, interdependence and various types of networks may produce dynamics that go beyond the Greek investment-Balkan immigration dipole. Obviously geographic proximity plays a very important role in making easier all kinds of flows and all forms of networks. Proximity though, in the Balkan context, is not only 
geographic but also cultural and social: nowadays, the Balkans seem to be regaining their former unified socio-cultural space (Mazower, 2000). There is no clear evidence if the patterns of mobility between Greece and certain Balkan countries as yet are indicative of some new expression of transnationalism. To what extent they can be labelled with the innovative meaning of the term, as defined, for instance, by Guarnizo and Smith (1998), is subject to further research and theorisation. However, the crossborder movements of people, goods, services and capital are by definition the type of flows which can be described by the neologism "transnational" and so are the processes conditioning immigrants' social incorporation in specific localities. Thessaloniki, a city with a long multicultural history in the past, has become a new home for immigrants from the Balkans, in a period of transforming local geographies and of growing interaction beyond national borders.

\section{BIBLIOGRAPHY}

ANDERSON B. (2001), "Reproductive labour and migration", Paper given at the Sixth International Metropolis Conference, Rotterdam, 26-30 November 2001.

BALDWIN-EDWARDS M. \& FAKIOLAS R. (1998), “Greece: the contours of a fragmented policy response", South European Society and Politics, 3, 3, pp.186-204.

CASTLES S. \& MILLER M. (2003), The age of migration: international population movements in the modern world, $3^{\text {rd }}$ edition, London, Macmillan.

CAVOUNIDIS J. \& HATZAKI C. (1999), Aliens who applied for the card of temporary residence: nationality, gender and spatial distribution, Athens, National Institute for Employment (in Greek).

CHRONAKI Z., HADJIMICHALIS C., LABRIANIDIS L. \& VAIOU D. (1993), “Diffused industrialisation in Thessaloniki: from expansion to crisis", International Journal of Urban and Regional Research, 17, 2 , pp. 178-194.

FAKIOLAS R. (2000), "Migration and unregistered labour in the Greek economy”, in KING R., LAZARIDIS G. \& TSARDANIDIS C. (eds.), Eldorado or fortress? Migration in Southern Europe, London, Macmillan Press, pp. 57-78.

GIANNAKOU A. \& KAFKALAS G. (1999), "Trends of spatial distribution of the tertiary sector and the regulation of urban development: lessons from the case of Thessaloniki”, in OIKONOMOU D. \& PETRAKOS G. (eds.), The development of Greek cities: interdisciplinary perspectives of urban analysis and policy, Volos, Thessaly University Press, Gutemberg (in Greek), pp. 93-115.

GUARNIZO L. E. \& SMITH M. P. (1998), “The locations of transnationalism”, in SMITH M.P. \& GUARNIZO L.E. (eds.), Transnationalism from below, New Brunswick, Transaction Publishers, pp. 3-31.

KAMARAS A. (2001), “A capitalist Diaspora: the Greeks in the Balkans”, The Hellenic Observatory Discussion Papers, 4, The European Institute, LSE.

KARYDIS V. (1996), The criminality of immigrants in Greece: problems of theory and anti-crime policy, Athens, Papazisis (in Greek). 
KING R (2000), "Southern Europe in the changing global map of migration”, in KING R., LAZARIDIS G. \& TSARDANIDIS C. (eds.), Eldorado or Fortress? Migration in Southern Europe, London, Macmillan Press, pp. 1-26.

KING R. \& ZONTINI E. (2000), “The role of gender in the South European immigration model”, Papers, Revista de Sociologia, 60, pp. 35-52.

LABRIANIDIS L., LYBERAKI A. TINIOS P. \& HATZIPROKOPIOU P. (2004), "Inflow of immigrants and outflow of FDI: aspects of interdependence between Greece and the Balkans", Journal of Ethnic and Migration Studies, 30 (in press).

LEONTIDOU L. (1997), "Five narratives of the Mediterranean city”, in KING R., PROUDFOOT L. \& SMITH B. (eds.), The Mediterranean: environment and society, London, Arnold, pp. 181-193.

MAZOWER M. (2000), The Balkans, Phoenix Press, London.

MUSTERD S., KESTELOOT C., MURIE A. \& OSTENDORF C. (2000), "Urban Social Exclusion and modes of integration: literature review”, Urbex Series, 1, Fourth RTD Framework Programme, TSER, AME, Amsterdam.

PAVLOU M. (2001), “The 'smugglers of fear': racist discourse and immigrants in the press of a potential metropolis”, in MAVRAKIS A., PARSANOGLOU D. \& PAVLOU M. (eds.), Immigrants in Greece, Athens, Society for Political Thinking "Nikos Poulantzas"/Ellinika Grammata (in Greek), pp. 127-162.

PORTES A. (1995), "Economic sociology and the sociology of immigration: a conceptual overview”, in PORTES A. (ed.), The economic sociology of immigration: essays on networks, ethnicity and entrepreneurship, New York, Russell Sage Foundation, pp. 1-41.

PSIMMENOS I. (1998), "Creating spaces of social exclusion: the case of Albanian clandestine immigrants at the centre of Athens", in KASIMATI K. (ed.), Social exclusion: the Greek experience, Athens, Centre for Social Morphology and Social Policy, Gutemberg (in Greek).

PSIMMENOS I. \& KASSIMATI K. (2002), "Shifting work identities and oppositional work narratives: the case of domestic and construction Albanian immigrants in Greece", Paper presented at the international conference Albanian Migration and the New Transnationalisms, University of Sussex, 6-7 September 2002.

PUGLIESE E. (1993), "Restructuring of the labour market and the role of the Third-World migrations in Europe", Environment and Planning - Society and Space, 11, 5, pp. 513-522.

SASSEN S. (1996), "New employment regimes in cities: the impact on immigrant workers", Journal of Ethnic and Migration Studies, 22, 4, pp. 579-594.

SYMEONIDOU, H. (1996), “Social protection in contemporary Greece”, Southern European Society and Politics, 1, pp. 67-86.

TRIANDAFYLLIDOU A. \& VEIKOU M. (2002), “The hierarchy of Greekness: ethnic and national identity considerations in the Greek immigration policy”, Ethnicities, 2 (2), pp. 189-208.

TRIANDAFYLLIDOU A., CALLONI M. \& MICRAKIS A. (1997), "New Greek nationalism”, in Sociological Research Online, 2, 1 (available online at: http://www.socresonline.org.uk/2/1/7.html).

VAIOU D. \& HADJIMICHALIS K. (1997), With the sewing machine in the kitchen and the Poles at the fields: cities, regions and informal labour, Athens, Exandas (in Greek). 


\section{NOTES}

1. Note also that the 2001 Census counted a total of $1,057,825$ residents in the prefecture $(68,848$ foreign nationals) with 93 per cent living in urban Thessaloniki.

2. Fieldwork investigation has been part of my ongoing DPhil research, supported by an ESRC doctoral studentship in Contemporary European Studies, and held at the Sussex European Institute (University of Sussex, UK), under the supervision of Professor Russell King, to whom I owe a lot for his help. I am also grateful to all respondents/interviewees as well as to many other people who helped me in various ways.

3. Ethnic Greek Albanians (or Northern Epeirotes, as the Greeks call them) are a recognised minority living mostly in, or originating from, villages and towns of Southern Albania. The majority of ethnic Greek Bulgarians belong to the cultural group of Sarakatsans, erstwhile nomad shepherds who are also located in parts of Northern Greece and Thessaly. After the Second World War, they found themselves at the other side of the border and settled south along the long mountainous line that divides Bulgaria, with their "capital" being the city of Sliven in the central-eastern part of the country.

4. 29 per cent of the Bulgarian women are divorced (and of them more than half have children). This possibly suggests that migration arises as an option for single-parent families with a female head, clearly showing the more independent character of Bulgarian female migration, compared to the mainly dependent nature of the female migration patterns in the Albanian case.

5. The spread of racism is also attributed to the mass media, especially the TV (see Pavlou, 2001). Another factor has been the nationalist paroxysm of the early 1990s, stimulated mainly by the "Macedonian question" and by the mid-1990s tensions in Greco-Turkish relations (Triandafyllidou et al., 1997).

6. The intermixing of different social areas of the city with both the indigenous and the immigrant populations makes it impossible to produce a meaningful map of immigrant segregation, quite apart from the lack of detailed base map sources.

7. It has to be stressed that it is basically informal social networks that condition this phenomenon, since there is not any ethnic infrastructure established in the area and the role of the Sarakatsans' associations in both Bulgaria and Greece remains unknown.

8. Personal interview with representatives of the association "Epeirote House" (active in Thessalonniki since 1940), a federation of several associations, including community associations of people originated from the Greek region of Epeiros, Northern Epeirote clubs and a "Friendship Union Korce-Thessaloniki".

\section{ABSTRACTS}

This paper examines three different contexts of incorporation of immigrants from Albania and Bulgaria in the Greek city of Thessaloniki: (a) at the socio-political level, focusing on the polity's and civil-society's "responses" to immigration; (b) at the socio-economic level, discussing the labour market integration of immigrants in Thessaloniki; (c) at the socio-spatial level, regarding the relation between immigration and urban dynamics. Within the transnational space that is being formed in the Balkans, Thessaloniki seems to have become a new home for migrants from Balkan countries. However, immigrants' lives in the city are determined by the socio-spatial and economic urban dynamics, which are subject to international forces of restructuring and change. 
Cet article examine l'intégration d'immigrants en provenance d'Albanie et de Bulgarie dans la ville grecque de Thessalonique à trois niveaux différents: (a) du point de vue socio-politique, en particulier les "réponses" de l'Etat et de la société civile au "problème" de l'immigration; (b) au niveau socio-économique, c'est-à-dire l'intégration des immigrés sur le marché du travail; (c) au niveau socio-spatial, en ce qui concerne les relations entre immigration et dynamiques urbaines. A l'intérieur de l'espace transnational qui se met en place dans les Balkans, Thessalonique semble être devenue un nouveau foyer d'accueil pour les migrants issus des pays balkaniques. Cependant, la vie des immigrants dans la ville est déterminée par des dynamiques urbaines sociospatiales et économiques dépendantes de forces internationales de restructuration et de changement.

\section{INDEX}

Mots-clés: intégration, Thessalonique, Balkans, transnationalisme

Keywords: incorporation, Thessaloniki, Balkans, transnationalism

\section{AUTHOR}

\section{PANOS HATZIPROKOPIOU}

Sussex European Institute, Arts A Building, University of Sussex, Falmer, Brighton, UK, panoshatziprokopiou@hotmail.com, P.A.Hatziprokopiou@sussex.ac.uk 